\title{
Transmission of the California Tobacco Rattle Virus (CTRV) by Three Species of the Nematode Genus Trichodorus'
}

\author{
Alejandro Ayala and M.W. Allen ${ }^{2}$
}

\section{INTRODUCTION AND REVIEW OF THE LITERATURE}

Soil-borne viruses and their mode of transmission have received much attention during the last few years. This is primarily because of the important discovery that some plant-parasitic nematodes $(16)^{3}$ and the chytrid fungus Olpidium brassicae (5) are capable of transmitting viruses from plant to plant. Information on the interrelationships of nematodetransmitted viruses and their vectors is rapidly increasing, especially with the nematode-transmitted polyhedral viruses. At present tubular-shaped viruses have not been so intensively studied.

Harrison (9) divided soil-borne viruses into several groups based on the shape of the particles, and those known to be transmitted by nematodes are found in two of those groups, both of which are characterized by loss of infectivity when the soil is dried (20). One group possessing polyhedralshaped particles with a diameter of about $30 \mathrm{~m} \mu$ was referred to as the "soil-borne ringspot viruses" by Harrison (9). More recently Cadman (4) suggested the term "NEPO-viruses," i.e., NEmatode-transmitted virus with POlyhedral particles. The second group includes the rod-shaped viruses called "NETU-viruses," i.e., NEmatode-transmitted viruses with TUbular particles (12). The NETU-viruses include two serologically distinct kinds, e.g., tobacco rattle virus (TRV) described by Behrens in 1899 (2), and pea early browning virus (PEBV) described by Bos and Van der Want in 1963 (3). Both are transmitted by several species of the nematode genus Trichodorus Cobb, 1913.

Tobacco rattle is now recognized as being more economically important

1 This is a portion of the thesis submitted in partial fulfillment of the requirements for the degree of Doctor of Philosophy in Nematology at the University of California, Davis, Calif. This research was supported in part by Research Grant No. 103746.04 of U.S.P.H.S., National Institutes of Health.

${ }^{2}$ Associate Nematologist of the Agricultural Experiment Station, Mayagüez Campus, University of Puerto Rico, and Professor of Nematology at the University of California, Davis, Calif., respectively. The authors wish to express gratitude to Prof. D. J. Raski for suggestions and the correction of the manuscript, and to Miss Ella Mae Noffsinger for valuable suggestions and proofreading of the manuscript; also to Professors F. S. Summers, Entomologist, and T. Shalla, Virologist, both of the University of California at Davis, who read the paper.

Italic numbers in parentheses refer to Literature Cited, pp. 124-5. 
than was previously thought, since it causes common diseases in Europe and North America $(19,81)$. It occurs in Florida (81), the Salinas Valley in California (19), and in Oregon (1). The strain used in the experiments reported here was obtained from the Salinas Valley where it occurs in lettuce, and is presumably the same reported previously from this locality. Sänger, Allen, and Gold (21) obtained the virus particle directly from the nematode, using this same strain.

The California tobacco rattle virus, referred to here as CTRV, was described by Gold et al. (8) from lettuce in the Salinas Valley of California. It is not related serologically to the Dutch strain of pea early browning virus (PEBV) as established in gel-diffusion tests. Its physical characters are as follows: half-life in vitro, 28 days; dilution end-point from $10^{-6}$ to $10^{-7}$; size of the large particles 196-197 $\mathrm{m} \mu$; size of the short particles, 107-109 $\mathrm{m} \mu$; ratio of long to short particles, 1.8:1; and width of particle approximately $21 \mathrm{~m} \mu$. The apparent size of the core in negatively stained preparations varies between 5 and $6 \mathrm{~m} \mu$. There seems to be a serological relationship between CTRV and TRV (Dutch strain) and not between PEBV (Dutch strain) and CTRV, the last two being much more alike morphologically (7).

In 1961 Sol and Seinhorst (24), Walkinshaw, Griffin, and Larson (32), and Harrison (10) demonstrated that the stubby root nematode was the vector of TRV and Atropa belladona mosaic virus. Eventually van Hoof in 1963 (29) demonstrated that T. pachydermus was the vector of PEBV. Later reports have shown that other species of Trichodorus also are capable of transmitting several isolates of both viruses. Consequently, several new species have been described and studies undertaken, but very little has been added to the knowledge of nematode-virus interrelationships.

In this study an attempt is made better to understand the interrelationships of CTRV and several species of Trichodorus, especially $T$. allius Jensen, 1963. To achieve this goal several aspects were investigated, such as the effectiveness of several species as vectors; minimum number of nematodes required to achieve transmission; efficiency in the transmission of different stages of the nematode; acquisition and inoculation minimum time; persistence of the virus in the nematode; retention through the molt; and transovarial transmission.

\section{MATERIALS AND METHODS}

\section{VIRUS-SOURCE AND CULTURING}

The California tobacco rattle virus source used in most experiments was obtained from lettuce, Lactuca sativa L. growing at the Salinas Valley, Calif. It was cultured on Glurk tobacco, Nicotiana tabacum L. var. Xanthinc and garden petunia, Petunia hybrida Vilm, under controlled conditions. A fresh source of virus was maintained by periodic mechanical inoculation 
of young tobacco seedlings. Only the growing point and youngest three leaves of the plants were used for the juice extraction. To keep healthy and virus-infected plants free of contamination by other viruses, plants were kept in complete isolation.

Mechanical transmission was performed using the corundum leaf-rubbing method. Plant tops and leaves were frozen, then thoroughly macerated in a mortar and pestle. Four to six drops of 0.05-M. sodium phosphate-citrate buffer solution ( $\mathrm{pH} 7.2$ ) were added to the macerate which was then filtered through a double sheet of sterile cheesecloth. The forefinger was used to rub the macerate on leaves, but in critical work, a small sterile cotton swab was soaked in the infected juice, then rubbed on the leaves of the indicator plants. After inoculation the leaves were washed with a gentle stream of tapwater from a plastic squeeze bottle. Treated plants were then placed in temperature tanks at $20^{\circ} \mathrm{C}$., or below, and covered with wrapping paper for 24 hours to prevent wilting.

\section{SOURCE AND MAINTENANCE OF NEMATODE POPULATIONS}

The nematode species tested in these studies were collected from several host plants in different localities in California and were cultured under different greenhouse conditions as follows: Trichodorus christiei Allen, 1957, Riverside isolate was obtained from soil about the roots of spinach at the University of California, Riverside Campus, and cultured on sweet corn; the Shafter isolate from soil about the roots of cotton at Shafter and populations maintained on cotton and alfalfa; $T$. porosus Allen, 1957 , from soil in a peach orchard treated with nematocides at Delhi increased on roots of cotton and alfalfa; T. allius from the Salinas Valley in soil about the roots of lettuce plants that were carrying CTRV, maintained on cotton at $21^{\circ} \mathrm{C}$., increased on sweet pea at $21^{\circ} \mathrm{C}$.

\section{RECOVERY OF NEMATODES}

Nematodes from field samples and greenhouse cultures were usually extracted from soil and roots by a combination of Cobb's screening and Baermann-funnel methods. At times a modified Seinhorst mist-chamber was used. Only two screens were used: the 60 -mesh to separate large debris such as plant and root materials, and the 200 - or 325 -mesh for recovering nematodes. The 200-mesh screen was used to isolate nematodes to be used in experiments, while the 325 was used for more critical recovery of nematodes from transmission and other experiments.

The procedure used with the Baermann-funnel method depended on the species of Trichodorus involved, and the purpose of the nematode recovery. Nematodes not to be used in further experiments were left in the funnels for 3 days, then recovered and counted by means of the counting dish and a 
stereoscopic microscope. When nematodes were to be used in experiments the samples of $T$. christiei and T. porosus were counted after 24 hours, but every 3 hours for 3 days for $T$. allius. Since nematodes of the latter species survived only short periods in unoxygenated water, they were used immediately after recovery, or were placed in a humidity air-chamber. In no case were nematodes used for transmission or biological experiments if they had been removed from the soil for more than 24 hours.

Viruliferous nematodes were sometimes picked directly out of plant and soil debris, although preliminary trials showed that extraction with the Baermann funnel did not reduce their efficiency as vectors. Other modifications were made according to the purpose of the experiment, details of which are given in the appropriate section.

\section{TRANSMISSION EXPERIMENTS}

Glurk tobacco was used in most of the experiments as the bait plant for CTRV, because it is a good host for T. allius, shows characteristic symptoms of CTRV damage, and is a fairly resistant plant to tobacco mosaic virus, thus preventing contamination by this virus. Nicotiana glutinosa L. was used, in some instances, as a bait plant. Chenopodium amaranticolor Coste and Reyn., was initially used as an assay plant, but was later replaced by cowpea, Vigna sinensis (Torner) Savi variety blackeye 5 , which is more sensitive, developing virus symptoms in 24 hours on 6 - to 9-day-old plants. All experiments were conducted at $20^{\circ} \mathrm{C}$. unless otherwise indicated, using constant-temperature baths or a growth-chamber.

One-month-old Glurk tobacco plants were usually transplanted into sterile soil, or soil-sand mixture, in clay pots $3,4,5$, or 6 inches in diameter, or in 100-cc. plastic beakers, and kept in a room at constant temperature, humidity, and light intensity until a sufficient number of roots had developed. The plants were then transferred to a selected temperature for 48 hours before CTRV was mechanically inoculated to the youngest leaves. In 4 to 10 days, when systemic symptoms started to appear, the desired number of nematodes was added. The length of time nematodes were allowed to feed before the original plants were replaced by "healthy" plants varied with the purpose of the experiment, but usually 10 days had elapsed before the original plants were cut. Ten days after setting the new seedlings, roots of the bait plants were carefully washed free of nematodes, and the roots, or the whole plants, were frozen in individual plastic bags until assayed for the virus. For all experiments, feeding, bait, and assay plants were selected of the same size, age, and vigor, and received the same treatment before and throughout the particular experiment. Control plants were also always included for each experiment to check on background contamination. 


\section{RESULTS AND OBSERVATIONS}

\section{TRANSMISSION BY A FIELD POPULATION OF $T$. allius}

For the transmission by a naturally infected population of $T$. allius, soil brought from the Salinas Valley, Calif., was thoroughly mixed in the laboratory with an equal amount of steam-sterilized greenhouse potting soil, and one-half of the resulting volume was then steam-sterilized. One week after sterilization nematode populations were assessed in five samples each of the sterilized and nonsterilized soil. An average of $45 \pm 7 \mathrm{~T}$. allius per $200 \mathrm{cc}$. of soil was recovered from the nonsterilized, and none were present in the sterilized soil. The sterilized and the nonsterilized soils were then placed separately in 203 -inch pots (200-cc. capacity) and set on a greenhouse bench.

TABLE 1.-Transmission of CTRV to Glurk tobacco by a field population of Trichodorus allius

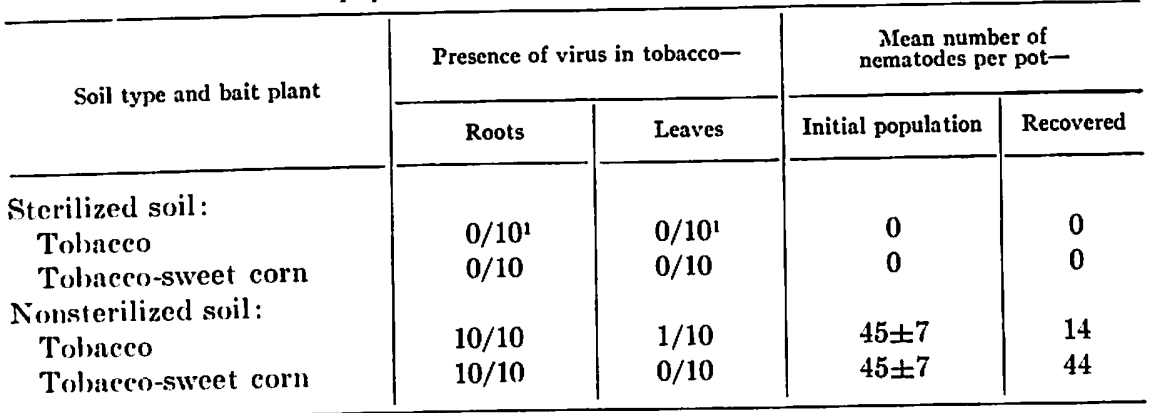

1 Vumerator $=$ plants showing virus; denominator $=$ plants used.

The bench had previously been covered with cheesecloth to render it insectproof.

The following treatments were used: 1 , Sterilized soil planted to Glurk tobacco plants; 2, sterilized soil planted to Glurk tobacco and three seedlings of sweet corn (Improved Bantam Early) in the same pot; 3, nonsterilized soil planted to Glurk tobacco; and 4, nonsterilized soil planted to Glurk tobacco and sweet corn in the same pot. Each treatment consisted of 10 replicates.

All the tobacco plants grown in the nonsterilized soil acquired the virus, while those in sterilized soil remained free (table 1). The number of lesions that appeared on indicator plants was greater from Glurk tobacco plants alone than when tobacco and sweet corn grew together. One Glurk tobacco plant showed systemic symptoms, but no virus was recovered from plant tops of the remaining bait plants. Systemic symptoms usually started as small spots on the leaves, extending to large concentric lines similar to those formed in mechanical transmission (figs. 1 and 2); a necrosis developed in 


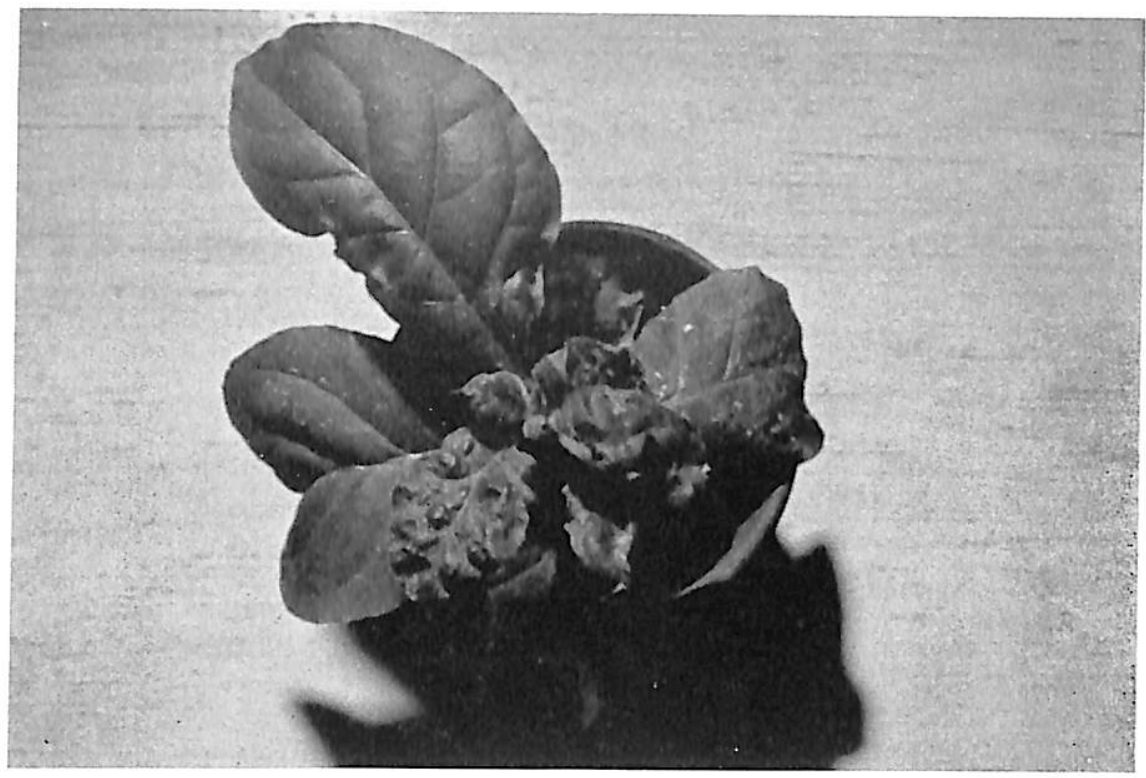

FIG. 1.-N. tabacum var. Xanthi-nc. Mechanically inoculated young plant showing severe symptoms of systemic CTRV infection.

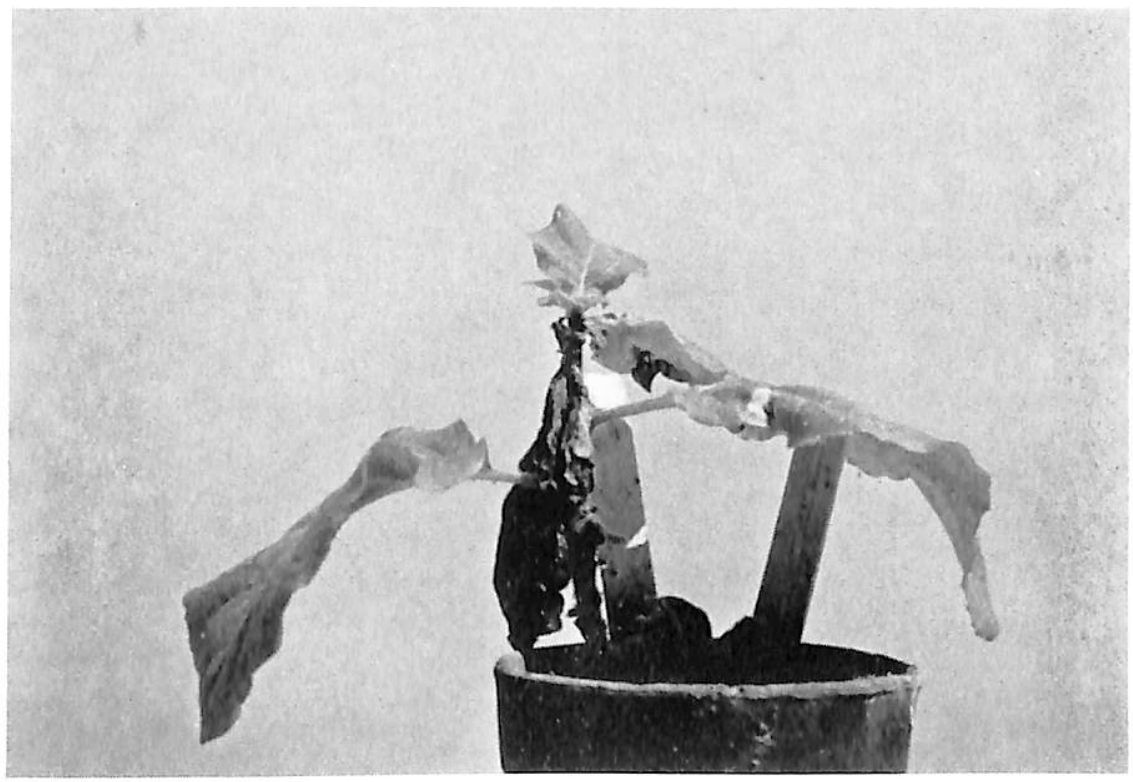

Fig. 2.- N. tabacum var. Manthi-ne. Old plant showing advance symptoms of CTRV when naturally infected by virus-infected T. allius. Notice large old leaves, arrested growth with dwarfed top leaves, and severe necrosis of stem below top two leaves and above dead leaves. 
the stem near the meristem and growth was arrested, causing severe stunting. The roots of three of these plants were used to isolate the virus which was then purified and identified serologically by the gel-diffusion tests and by electron microscopy as CTRV. Virus was not recovered from the roots of sweet corn, a fact that differentiates this strain of TRV from potato corky ringspot (American strain of TRV).

Nematode recovery was rather inconsistent. Populations from Glurk tobacco alone were lower than those from tobacco and sweet corn together. Nematodes were not recovered from three of the pots with Glurk tobacco where virus transmission took place. The experiment was carried out during the summer when greenhouse ambient temperatures fluctuated between 18 to $35^{\circ} \mathrm{C}$. $T$. allius frequently does not reproduce and survive well under these conditions, although it feeds and transmits the virus. This is the probable explanation for instances of transmission where nematodes were not recovered at the temination of the experiment.

\section{SCREENING SPECIES AS VECTORS}

Six isolates of four Trichodorus species were tested as potential vectors of CTRV. Environmental requirements of each species were extremely varied; therefore no attempt was made to compare their ability to transmit the virus in one compound experiment. The different species and isolates were tested in separate experiments using a varied number of bait or test plants all experiments were conducted at $20^{\circ} \mathrm{C}$.

A modification of the double-plant test was used in most cases. Nematodes were allowed to feed for 15 to 22 days on virus-infected plants. The virus plant was then cut and a "healthy" plant set in the pot and allowed to grow for 15 to 22 days. In other tests, the nematodes were allowed to feed on virus-infected Glurk tobacco plants then recovered, hand-picked, and flushed with water into soil around roots of "healthy" bait plants.

Trichodorus allius proved to be the most effective vector, as all plants exposed to 25 viruliferous nematodes of this species became infected with CTRV (table 2).

Suitability of the bait plant to nematode feeding greatly influenced the results. One hundred $T$. christiei (Riverside isolate) failed to transmit CTRV from Glurk tobacco to seedlings of the same plant. This failure to transmit the virus apparently resulted from the inability of the nematode to feed on the roots of this plant species. The same nematode isolate (100 specimens) transmitted the virus to 60 percent of the plants when California Wonder pepper was used both as a source of virus for the nematode (referred to as the "feeding plant") and as a bait plant. Positive results were also obtained when this isolate fed on virus-infected Nicotiana glutinosa 
and then transferred to blackeye cowpea. Results were erratic when $N$. glutinosa was used both as a feeding and as a bait plant.

The Shafter isolate of T. christiei (300 specimens) transmittedi CTRV to 30 percent of the Glurk tobacco plants after feeding on similar virusinfected plants. This population did not transmit the virus from $N$. glutinosa to $N$. glutinosa. Attempts to transmit CTRV with the sugar beet isolate of $T$. christiei gave negative results. Either the nematode did not feed on Glurk tobacco or the number of nematodes added (50) was not high enough to accomplish transmission.

Trichodorus porosus, after feeding both on Glurk tobacco and N. glutinosa transmitted the virus to 57 percent of the $N$. glutinosa used as bait plants.

TABLE 2.-Transmission of CTRV by 6 isolates of Trichodorus sp.

\begin{tabular}{|c|c|c|c|c|c|c|}
\hline \multirow{2}{*}{ Nematode species and isolate } & \multirow{2}{*}{ Source of virus } & \multirow{2}{*}{ Bait plant } & \multicolumn{2}{|c|}{$\begin{array}{l}\text { Infection of } \\
\text { bait plants }\end{array}$} & \multicolumn{2}{|c|}{$\begin{array}{l}\text { Number of } \\
\text { nematodes }\end{array}$} \\
\hline & & & $\begin{array}{l}\text { Inocu- } \\
\text { lated }\end{array}$ & $\begin{array}{l}\text { Virus } \\
\text { recov- } \\
\text { ered }\end{array}$ & Initial & $\begin{array}{l}\text { Mean } \\
\text { recov- } \\
\text { ered }\end{array}$ \\
\hline $\begin{array}{l}\text { Trichodorus christici: } \\
\text { Riverside isolate } \\
\text { Do. } \\
\text { Shafter isolate } \\
\text { Sugar beet isolate } \\
T \text {. allius } \\
\text { Do. } \\
T \text {. porosus } \\
\text { Do. } \\
T \text {. californicus }\end{array}$ & $\begin{array}{c}\text { Glurk tobacco } \\
\text { Pepper } \\
\text { Glurk tobacco } \\
\text { do. } \\
\text { do. } \\
N . \text { glutinosa } \\
\text { do. } \\
\text { Glurk tobacco } \\
\text { do. }\end{array}$ & $\begin{array}{c}\text { Glurk tobacco } \\
\text { Pepper } \\
\text { Glurk tobacco } \\
\text { do. } \\
\text { do. } \\
\text { N. glutinosa } \\
\text { do. } \\
\text { do. } \\
\text { Glurk tobacco }\end{array}$ & $\begin{array}{r}9 \\
10 \\
10 \\
10 \\
12 \\
10 \\
8 \\
6 \\
12\end{array}$ & $\begin{array}{r}0 \\
6 \\
3 \\
0 \\
12 \\
10 \\
3 \\
5 \\
0\end{array}$ & $\begin{array}{r}100 \\
100 \\
300 \\
50 \\
28 \\
10 \\
100 \\
100 \\
30\end{array}$ & $\begin{array}{r}47 \\
52 \\
24 \\
3 \\
72 \\
87 \\
601 \\
115 \\
1\end{array}$ \\
\hline
\end{tabular}

Eighty-three percent of the bait plants acquired CTRV after nematodes were fed on infected Glurk tobacco, but when nematodes were fed on $N$. glutinosa only 58 percent of the bait plants became infected.

Trichodorus californicus failed to transmit CTRV using Glurk tobacco. Only 30 nematodes were added per pot, but a few adults were recovered at the end of the experiment. There was no indication that this nematode had fed on the roots of tobacco.

\section{MINIMUM NUMBER OF NEMATODES REQUIRED FOR TRANSMISSION}

The minimum number of Trichodorus allius required to achieve transmission of CTRV was determined in an experiment using three different population levels. Nicotiana glutinosa seedlings served as bait plants and were set in 5-inch pots containing steam-sterilized soil, and set in a constant-temperature water bath at $20^{\circ} \mathrm{C}$. Individual viruliferous nematodes 
were hand-picked, rinsed in distilled water, and added in numbers of 1,5 , and 10 per plant to each of 5 pots in each treatment.

Results obtained after a 28-day access period (table 3) demonstrate that 10 nematodes were enough to transmit CTRV to 100 percent of the bait plants. One nematode was capable of virus transmission to 60 percent of the bait plants, while five of them transmitted the virus to 80 percent of the plants. No nematodes were recovered from the pots receiving only one, but large numbers were obtained from the other two treatments. The large volume of soil used (500 cc.) did not permit washing all the soil contained in a pot, and this may account for the failure to recover nematodes from the lowest population level.

\section{TRANSMISSION OF CTRV BY DIFFERENT LIFE STAGES OF T.allius}

Ten T. allius of all stages were sufficient to achieve 100-percent transmission when infective nematodes had access to virus-free bait plants. In a

TABLE 3.-Transmission of CTRV to Nicotiana glutinosa by different population levels of Trichodorus allius

\begin{tabular}{c|c|c|c}
\hline $\begin{array}{c}\text { Initial nematode } \\
\text { populations }\end{array}$ & Number of plants & $\begin{array}{c}\text { Bait plants } \\
\text { acquiring virus }\end{array}$ & Percentage transmission \\
\cline { 1 - 2 } & 5 & 0 & 0 \\
1 & 5 & 3 & 60 \\
5 & 5 & 4 & 80 \\
10 & 5 & 5 & 100 \\
\hline
\end{tabular}

second experiment including 10 second-stage larvae per pot, 50 percent of the bait Glurk tobacco plants became infected with CTRV which caused an average of 10 lesions per plant. This suggested the possibility that CTRV is transmitted with different degrees of efficiency by different stages of the nematodes. A third experiment was carried out to investigate transmission efficiency for the different developmental stages, and the number of nematodes of that particular stage necessary to transmit virus to all the plants. Identification of larval stages was based on genital organ development, relative size, and body width. As males are very rare they were not included in the study.

A population of $T$. allius recovered from a virus-infected Glurk tobacco plant were hand-picked. Adult females and larvae of each stage were selected and rinsed in distilled water and used in groups of 1,5 , and 10 per plant to inoculate Glurk tobacco plants set in a 3:1 coarse sand-soil mixture. Each inoculation was replicated 6 times. Controls for each group of nematodes consisted of plants without nematodes.

All nematode stages were efficient in transmitting CTRV (table 4). 
Adults were apparently the most efficient vectors, as single females transmitted the virus to all inoculated plants. Large numbers of lesions developed on the indicator plants receiving sap from roots exposed to 5 and 10 nematodes of each stage. The 5 or 10 nematodes of each stage were sufficient to inoculate CTRV to all the plants exposed, except third-stage larvae where five nematodes tranmitted the virus to only 83.3 percent of the bait plants. Nematodes were recovered even when only one was added per pot, except with second- and third-stage larvae where recovery was low (50 and 33 percent, respectively). On two occasions virus transmission took place when nematodes were not recovered. This indicates that the nematodes

TABLE 4.-Transmission of CTRV by 8 different population levels of adult females and \& larval stages of Trichodorus allius

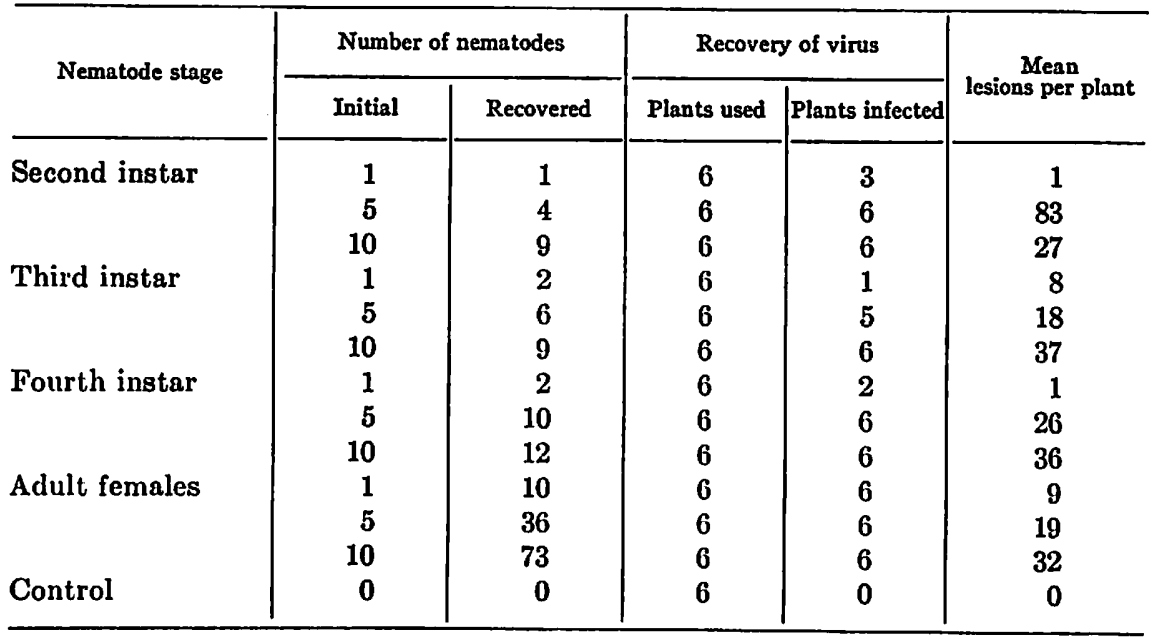

survived long enough to transmit the virus before dying, or were lost during the recovery process. In most cases when virus was not detected at harvesttime the nematodes were still present which suggests that failure to transmit resulted from variations in infectivity of the population rather than death of the nematodes. The number of nematodes recovered and the virus lesions on assay plants were always proportional to the number of nematodes added except with second-stage larvae. The number of lesions produced from root extracts of plants exposed to 5 second-stage larvae was higher than those exposed to 10 nematodes of the same stage.

\section{MINIMUM ACQUISITION TIME}

The exact time a nematode population must feed on a virus-infected plant to acquire the virus and become capable of transmitting it to another plant 
has not been determined. An attempt was made to determine the minimum feeding time of T. allius on a CTRV-infected tobacco plant before it would become infective, but without success. Therefore the intervals mentioned here should be regarded as access time, as nematodes were not observed feeding in the particular experiments.

To study the minimum time required (access period) for $T$. allius to inoculate CTRV into a healthy tobacco plant, nematodes exposed to infected plants for different intervals of time in 100-cc. plastic beakers containing a 3:1 mixture of coarse sand and greenhouse potting soil were transferred to healthy plants. For this a population of $50 \pm 8$ nematodes was fed in a mechanically inoculated Glurk tobacco plant.

The following access periods were allowed before nematodes were recovered: $1,2,4,8,12$, and 16 hours and $1,2,3,4,5,6,7,8,9$, and 10 days. After recovery, the nematodes in each sample were allowed to settle at the bottom of a plastic cup. The supernatant water was then poured off and the remainder containing the nematodes was added around the roots of a second Glurk tobacco seedling set in a 4 -inch clay pot and held at $20^{\circ} \mathrm{C}$. The plants were harvested 12 days after being exposed to the nematodes. At this time the plant roots were carefully washed free of soil and assayed for the presence of virus on the primary leaves of 9-day-old blackeye cowpea plants and the nematodes were recovered and counted.

The nematodes acquired CTRV within an hour of being added to the virus-infected plant as one of the bait plants became infected, though few lesions developed. Nematodes that had fed for 2 hours infected two of the bait plants. The number of plants showing virus symptoms increased as feeding intervals increased up to 24 hours, except for the 4-hour period when only one plant became infected. One hundred-percent transmission was obtained when nematodes had access to virus-infected plants for 24 hours, or more, except for those from the second and sixth day when only five plants of each became infected. Virus was not recovered from control plants (table 5).

The mean number of lesions per plant increased up to the 24-hour access interval, after which the results varied greatly. Virus titer in the plant inoculated by a nematode population apparently increased with longer feeding periods up to 24 hours, after which extended intervals of feeding did not influence the number of lesions produced on the assay plants. The number of lesions was highest when nematodes were fed on CTRV plants for 5 days.

\section{MINIMUM INOCULATION TIME}

Two separate experiments were carried out to determine the time a viruliferous nematode population must have access to a healthy Glurk tobacco plant in order to transmit virus. As in the previous case, the inter- 
vals should be regarded as access periods rather than feeding periods. In the first experiment viruliferous $T$. allius were allowed to feed on roots of tobacco seedlings for 15 different time-intervals ranging from 1 hour to 10 days (table 6). The second experiment included seven treatments with feeding times of 1 hour to 3 days.

Two-month-old Glurk tobacco seedlings set in 100-cc. beakers containing a 3:1 mixture of coarse sand and soil were used in the first experiment. Each treatment was replicated six times. A population of 25 T. allius including

Table 5.-Transmission of CTRV by Trichodorus allius populations fed on virus-infected Glurk tobacco plants for different time intervals

\begin{tabular}{|c|c|c|c|c|c|}
\hline \multirow{2}{*}{$\begin{array}{l}\text { Feeding interval } \\
\text { (hours) }\end{array}$} & \multicolumn{2}{|c|}{ Virus transmission } & \multirow{2}{*}{$\begin{array}{l}\text { Mean number } \\
\text { of lesions per plant }\end{array}$} & \multicolumn{2}{|c|}{ Mean number of nematodes } \\
\hline & $\begin{array}{c}\text { Plants } \\
\text { inoculated }\end{array}$ & $\begin{array}{l}\text { Plants in- } \\
\text { fected with } \\
\text { virus }\end{array}$ & & Initial & Recovered \\
\hline 1 & 6 & 1 & 1.3 & $50 \pm 8$ & 134 \\
\hline 2 & 6 & 2 & 2.7 & $50 \pm 8$ & 104 \\
\hline 4 & 6 & 1 & 1.5 & $50 \pm 8$ & 68 \\
\hline 8 & 6 & 2 & 5.2 & $50 \pm 8$ & 127 \\
\hline 16 & 6 & 4 & 5.7 & $50 \pm 8$ & 83 \\
\hline 24 & 6 & 6 & 27.6 & $50 \pm 8$ & 53 \\
\hline 48 & 6 & 5 & 23.2 & $50 \pm 8$ & 203 \\
\hline 72 & 6 & $\mathbf{6}$ & 21.3 & $50 \pm 8$ & 86 \\
\hline 96 & 6 & 6 & 26.0 & $50 \pm 8$ & 131 \\
\hline 120 & 6 & 6 & 44.3 & $50 \pm 8$ & 141 \\
\hline 144 & 6 & 5 & 19.2 & $50 \pm 8$ & 171 \\
\hline 168 & 6 & 6 & 34.2 & $50 \pm 8$ & 105 \\
\hline 192 & 6 & 6 & 36.7 & $50 \pm 8$ & 65 \\
\hline 216 & 6 & 6 & 3.6 & $50 \pm 8$ & 80 \\
\hline 240 & 6 & 6 & 5.0 & $50 \pm 8$ & 84 \\
\hline
\end{tabular}

all stages, were allowed a 10-day access period in mechanically inoculated tobacco plants. The viruliferous nematodes were then recovered and added to 2-month-old Glurk tobacco seedlings set in 100-cc. plastic beakers. The nematodes had access to the infected plants for the following periods of time: $1,2,4,8$, and 16 hours, and $1,2,3,4,5,6,7,8,9$, and 10 days.

After every indicated interval of time six pots were harvested, the roots thoroughly washed free of soil and rinsed with a strong stream of water and the whole plant placed in a plastic beaker with water for 1 hour. The roots were observed under a binocular, washed and rinsed again before being set finally in sterilized soil contained in a 4-inch clay pot, and placed in a $20^{\circ} \mathrm{C}$. temperature tank. The plants were allowed to grow for 15 days after being freed from nematodes. The roots from each plant were then washed free of 
soil and assayed for the presence of CTRV on the leaves of blackeye cowpea. Nematode counts were made at the time of freeing plants from nematodes and at the end of the experiment as a further check to insure that plants were completely free of nematodes.

In this test transmission was obtained in 8 hours. No virus was recovered when plants were exposed to viruliferous nematodes from 1 to 4 hours, and for 24 hours (table 6). Two plants each from the 8- and 16-hour access intervals acquired the virus although the number of lesions was very low. All plants exposed to infective nematodes for 9 and 10 days became infected

TABLE 6.-Transmission of CTRV to healthy Glurk tobacco roots, exposed to infective Trichodorus allius, in relation to feeding intervals

\begin{tabular}{|c|c|c|c|c|c|c|}
\hline \multirow{2}{*}{$\begin{array}{l}\text { Exposure time } \\
\text { (hours) }\end{array}$} & \multicolumn{2}{|c|}{ Presence of virus } & \multirow{2}{*}{$\begin{array}{l}\text { Mean lesions } \\
\text { per plant }\end{array}$} & \multicolumn{3}{|c|}{ Nematode populations } \\
\hline & Plants used & Infected & & Initial & $\begin{array}{c}\text { After feeding } \\
\text { period }\end{array}$ & Harvesttime \\
\hline 1 & 6 & 0 & 0 & 25 & 80 & 0 \\
\hline 2 & 6 & 0 & 0 & 25 & 116 & $\mathbf{0}$ \\
\hline 4 & 6 & $\mathbf{0}$ & 0 & 25 & 140 & $\mathbf{0}$ \\
\hline 8 & 6 & 2 & 1 & 25 & 96 & 0 \\
\hline 16 & 6 & 2 & 1 & 25 & 133 & $\mathbf{0}$ \\
\hline 24 & 6 & $\mathbf{0}$ & 0 & 25 & 100 & 0 \\
\hline 48 & 6 & 1 & 1 & 25 & 108 & 0 \\
\hline 72 & 6 & 1 & 3 & 25 & 89 & 0 \\
\hline 96 & 6 & 5 & 9 & 25 & 120 & 0 \\
\hline 120 & 6 & 5 & 5 & 25 & 120 & 0 \\
\hline 144 & 6 & 5 & 17 & 25 & 132 & $\mathbf{0}$ \\
\hline 168 & 6 & 5 & 6 & 25 & 140 & 0 \\
\hline 192 & 6 & 4 & 5 & 25 & 114 & 0 \\
\hline 216 & 6 & 6 & 7 & 25 & 149 & 0 \\
\hline 240 & 6 & 6 & 6 & 25 & 159 & 0 \\
\hline
\end{tabular}

with CTRV. The number of lesions produced in cowpea indicator plants remained low in most treatments, suggesting that 2-month-old plants are not very sensitive to nematode-injected virus, or that a low number (only 25) of nematodes was not sufficient to transmit virus in a short interval. Nematode populations recovered after each inoculation period was high, but no nematodes were recovered at harvesttime demonstrating that plants were completely free of nematodes.

A second experiment was conducted to determine the cause of the inconsistency of results obtained in the first experiment. All methods and conditions remained the same as in the first experiment, except that 1month-old tobacco plants about $10 \mathrm{~cm}$. high were used both as source of virus for the nematode and as bait plants. Seven treatments were used and 
the feeding intervals ranged from 1 hour to 3 days. The nematode inoculum consisted of $238 \pm 20$ per pot.

Viruliferous nematodes inoculated the virus within 1 hour after being added to indicator plants as 33 percent of the plants acquired the virus when exposed to infective nematodes. Efficiency of transmission seemed to improve as exposure interval was increased up to 48 hours when all plants became infected. At the 24 - and 72 -hour feeding intervals only 66 percent of the plants became infected (table 7).

There were no marked differences in nematode populations among treatments after each feeding interval. This may be because of the short periods of time that the plants were exposed, and the reduced root system of the plants that did not permit high reproduction. Nematodes were not re-

TABLE 7.-Transmission of CTRV to healthy Glurk tobacco exposed to viruliferous Trichodorus allius in relation to feeding time

\begin{tabular}{|c|c|c|c|c|c|c|}
\hline \multirow{2}{*}{$\begin{array}{l}\text { Exposure time } \\
\text { (hours) }\end{array}$} & \multicolumn{2}{|c|}{ Virus transmission } & \multirow{2}{*}{$\begin{array}{l}\text { Mean lesions } \\
\text { per plant }\end{array}$} & \multicolumn{3}{|c|}{ Nematodes recovered } \\
\hline & Plants used & $\begin{array}{c}\text { Plants ac- } \\
\text { quiring } \\
\text { virus }\end{array}$ & & Inoculated & $\begin{array}{l}\text { After feeding } \\
\text { period }\end{array}$ & 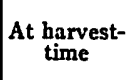 \\
\hline 1 & 6 & 2 & 1 & $238 \pm 20$ & 196 & $\mathbf{0}$ \\
\hline 2 & 6 & 4 & 16 & $238 \pm 20$ & 183 & 0 \\
\hline 4 & 6 & 5 & 9 & $238 \pm 20$ & 257 & 0 \\
\hline 8 & 6 & 5 & 10 & $238 \pm 20$ & 225 & 0 \\
\hline 16 & 6 & 5 & 35 & $238 \pm 20$ & 225 & $\mathbf{0}$ \\
\hline 24 & 6 & 4 & 18 & $238 \pm 20$ & 129 & 0 \\
\hline 48 & 6 & 0 & 23 & $238 \pm 20$ & 165 & 0 \\
\hline 72 & 6 & 4 & 24 & $238 \pm 20$ & 135 & $\mathbf{0}$ \\
\hline
\end{tabular}

covered at harvesttime, showing that the access periods reported here are accurate, and the technique used for freeing the bait plants of nematodes after each period was efficient. Both factors are of primary importance in an experiment of this nature.

\section{PERSISTENCE OF CTRV IN T. allius}

The length of time $T$. allius will remain viruliferous after feeding on a virus-infected plant is not known. During these studies a population of originally infective $T$. allius lost the ability to transmit CTRV after feeding on sweet pea and cotton roots for 3 months, but infectivity was not lost when the nematodes fed on lettuce of the variety Great Lakes 118 for the same period of time. In transmission experiments only populations feeding on virus-infected plants for short periods of time (5 to 22 days) were employed. These nematodes were never used in more than one experiment. 
Two separate experiments were conductd to investigate the length of time a viruliferous nematode population remains infective. The experiments were carried out simultaneously in a constant-temperature water bath at $20^{\circ} \mathrm{C}$.

In the first experiment, 200 nematodes fed on a virus-infected plant for 5 days were recovered and added to each of 60 (100 cc.) plastic beakers containing a mixture of coarse sand and soil (3:1) but no plant. Every week for 3 months, and once monthly thereafter, a young Glurk tobacco plant was set in each of five pots and exposed to the nematodes present. After a 15-day access period, five plants were taken up, their roots washed free of nematodes, and assayed for virus on cowpea leaves, and the nematodes were recovered and counted.

In the second experiment, 50 viruliferous nematodes were added to 100 cc. beakers which contained two germinated CTRV immune sweetpea seedlings. Every week for 3 months, and once monthly thereafter six sweetpea plants were replaced by a healthy Glurk tobacco seedling in each of six pots. Roots of the bait plants were assayed on cowpea 2 weeks later for the presence of virus and the nematodes were recovered and counted.

The first population of $T$. allius was still infective after 20 weeks (140 days), and the second population was still capable of transmitting the virus to the bait plants after 27 weeks (189 days) (fig. 3 ). In both cases 100-percent transmission was still obtained at the end of the experiments indicating that both populations were highly viruliferous. Fluctations occurred in the number of lesions produced and percentage of transmission. This may have been attributed to failure of particular populations to become infective, or some of the feeding plants were not virus-infected. Nematode populations increased rapidly when feeding on sweetpea, approaching a peak after 8 weeks, but decreased steadily under fallow conditions. The number of lesions seemed to decrease with time interval when the nematode had fed on sweetpea. The experiments were terminated when nematode populations died out, indicating that once a population becomes infected it remains infective until death.

\section{TRANSOVARIAL TRANSMISSION OF CTRV}

The possibility exists that nematode-vectored viruses can be transmitted to the progeny through the egg. This aspect has been studied by a few workers and the results have been negative. To investigate this aspect T. allius was used with CTRV.

Adult females were selected from a large population feeding on virusinfected plants and were added to pots containing three plants of virusimmune sweetpea (Floribunda mixed variety). From this nematode population three different larval stages were separated (second, third, and fourth), rinsed in distilled water, and added in groups of 10 to each of 30 young 
Glurk tobacco plants grown in 100-cc. plastic beakers in a mixture of coarse sand and potting soil (3:1).

Fourteen days later, the roots of each plant were washed free of soil and assayed for virus, and the nematodes recovered and counted. Except for 1 of the 11 plants exposed to third-stage larvae, none of the 30 plants became infected with CTRV (table 8). Adults from the same population were used

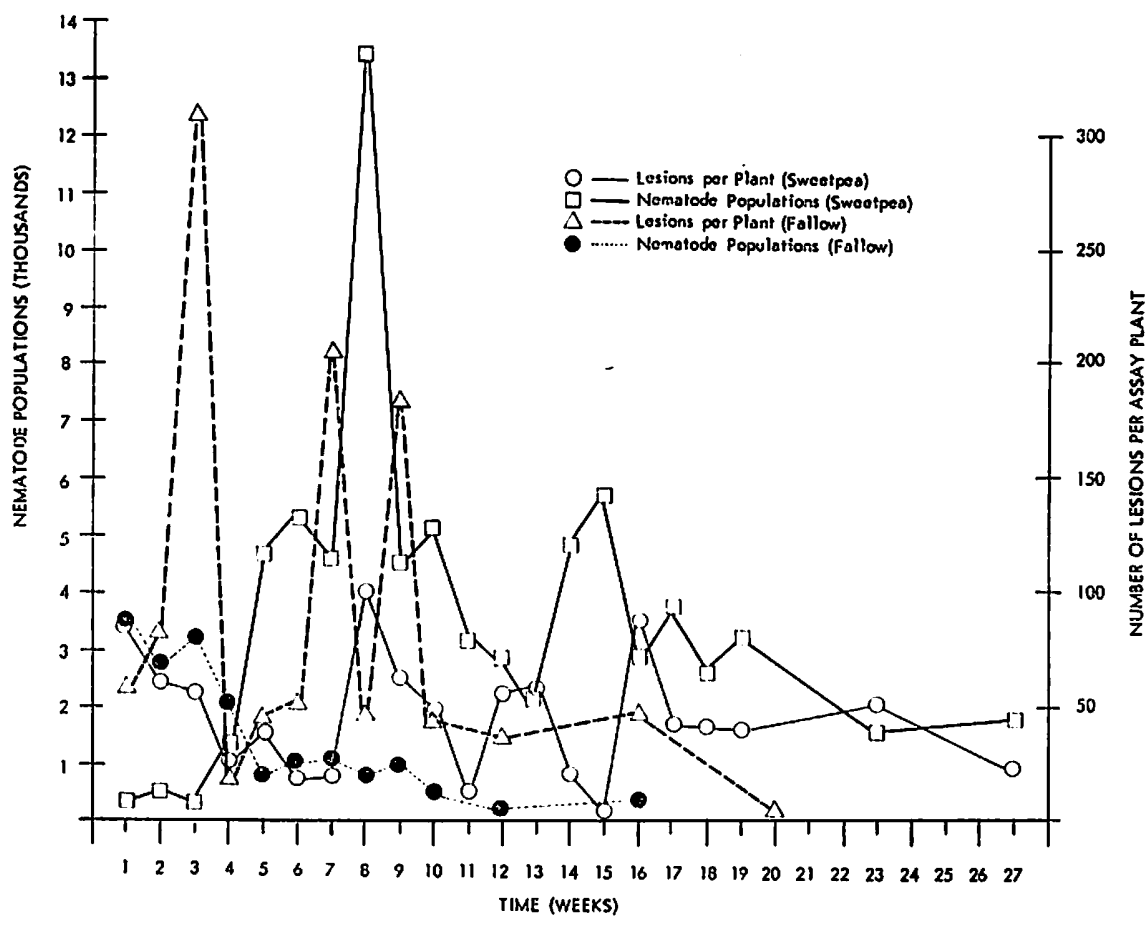

Fig. 3.-Number of lesions per plant, and nematode populations in the study of CTRV persistence in or on $T$. allius under fallow conditions, and while feeding on a virus-immune host (Sweetpea).

as controls, and four out of five bait plants exposed to them became infected thus demonstrating that the original population was infective. Results therefore, suggest that CTRV is not transmitted to the progeny through the eggs.

\section{VIRUS RETENTION THROUGH NEMATODE MOLTS}

California tobacco rattle virus retention through the molts of $T$. allius was investigated under controlled conditions. Three different larval stages (second, third, and fourth) were separated and added to roots of sweetpea (Floribunda mixed variety) after 6 days of feeding on virus-infected Glurk 
tobacco plants. Three weeks later nematodes from each culture were recovered and the adults and different larval stages were separated and added in groups of five each per indicator plant. Only the preceding and next developmental stage to the one originally inoculated were used, thus avoiding the original nematodes. In this way nematodes of the second generation and those having molted one to three times were tested for virus transmission.

After 14 days, the roots of each plant were washed free of soil, assayed for virus, and the nematodes were recovered and counted. Results indicated that it is unlikely that transovarial transmission took place. None of the first- or second-generation larval stages transmitted CTRV to the bait plants. Adults, previously added as second-stage larvae, were able to infect two out of seven bait plants with CTRV. During this time these nematodes

TABLE 8.-Transmission of CTRV to Glurk tobacco by different stages of Trichodorus allius infective in the prior generation

\begin{tabular}{l|c|c|c|c|c}
\hline \multirow{2}{*}{ Nematode stage } & \multicolumn{2}{|c|}{ Recovery of virus } & Number of nematodes \\
\cline { 2 - 5 } & Plants used & $\begin{array}{c}\text { Plants } \\
\text { infected }\end{array}$ & Lcsions per plant & Initial & Recovered \\
\cline { 2 - 5 } & 11 & 0 & 0 & 10 & 8 \\
Second instar & 11 & 1 & 1 & 10 & 8 \\
Third instar & 8 & 0 & 0 & 10 & 11 \\
Fourth instar & 5 & 4 & 5 & 10 & 14 \\
Adult females & 5 & &
\end{tabular}

had molted three times. All females used were of the first generation, but females originally added as third- and fourth-stage larvae did not transmit the virus. The reason for loosing virus through one and two molts, and not in all cases when three molts have taken place is not clearly understood. Further research is needed before definite conclusions can be reached.

\section{RECOVERY OF CTRV IN FEMALES OF T. Allius}

To study the possibility of recovering the virus directly from the nematode, three different population levels that had already been tested for transmission to bait plants were used. Adult females fed on mechanically infected Glurk tobacco for 22 days were isolated into groups of 1,5 , and 10 specimens. Each population level was replicated 11, 9, and 7 times, respectively. The nematodes of each replicate were cut into several pieces on a drop of water on top of a piece of cellulose, then a drop of cold phosphate buffer was added. Any effect of heat from the microscope lamp was avoided by placing the cellulose on top of a Petri dish filled with distilled water and set on the microscope stage. Distilled water in the Petri dish was replaced 
after every five cuttings, and the cellulose and eye-knife used for cutting were thoroughly washed with hot water and then distilled water after every cut. The resulting solution was rubbed on a blackeye cowpea leaf dusted with corundum. All treatments and controls were compared by the opposite leaf method.

Symptoms of virus infection developed in some of the leaves 3 days after inoculation. When single lesions were back-inoculated to Glurk tobacco plants, typical CTRV symptoms developed in 24 hours. Only one of the indicator plants developed lesions when inoculated with the cuttings of a single nematode. Very few symptoms developed from the cuttings of 5 and 10 nematodes (table 9). Four out of nine assay plants receiving the extract of five nematodes showed virus symptoms, while only 2 out of the 7 from the 10-nematode level developed lesions.

TABLE 9.-Direct recovery of CTRV from infective Trichodorus allius

\begin{tabular}{c|c|c|c}
\hline Nematodes used & Leaves inoculated & $\begin{array}{c}\text { Leaves showing } \\
\text { symptoms }\end{array}$ & $\begin{array}{c}\text { Total number of lesions } \\
\text { in indicators }\end{array}$ \\
\hline 0 & 5 & 0 & 0 \\
1 & 11 & 1 & 2 \\
5 & 9 & 4 & 15 \\
10 & 7 & 2 & 4 \\
\hline
\end{tabular}

\section{DISCUSSION}

Three out of four species of the genus Trichodorus tested as vectors transmitted California tobacco rattle virus (CTRV) from virus-infected plants to "healthy" bait plants. Two isolates of T. christiei (Riverside, and Shafter isolates) varied in their efficiency as vectors of the virus and usually large numbers of the nematode were required. Failure to transmit virus with a sugar beet isolate of the same species and with $T$. californicus may have been because of the low number of nematodes used, and the bait plant employed, rather than inability of the nematode to inoculate virus. Trichodorus christiei also transmits the American isolate of TRV (31), but 50 to 150 nematodes were necessary to inoculate the 82 percent of the bait plants. Apparently T. christiei is not a very efficient vector of either of the two viruses. Walkinshaw, et al. (31) used corn as an intermediate or bait plant to improve results because it was a good host for both the virus and the nematode. In our experiments corn was not used, because it is not a host of CTRV, and nematodes lost infectivity after feeding on its roots for 2 to 3 months.

Trichodorus porosus has not been reported in the literature to be a vector of TRV or PEBV, but it is here reported as a vector of CTRV. It is not a 
very efficient vector because only 57 percent of the bait plants became infected with the virus when exposed to 100 viruliferous $n$ ematodes.

Jensen and Allen (17) found T. allius to be the vector of the Oregon isolate of TRV. This species is an excellent vector of the related CTRV, providing another example of a nematode species that transmits two different strains of a virus. This, as in the case of T. christiei, supports Van Hoof's (28) doubts about the hypothesis of Harrison, et al. (14) concerning specificity of nematode species to transmit only one strain of a virus. Van Hoof (28) reported T. pachydermus is a vector of PEBV and the serologically unrelated virus, tobacco rattle virus (24). Longidorus elongatus, is the vector of tomato black ring virus (14) and also transmits raspberry ringspot virus (25) which is serologically unrelated to the former. Xiphinema americanum transmits tomato ringspot virus, peach yellow bud mosaic virus, and grape yellow vein virus (27).

A field population of $45 \mathrm{~T}$. allius of all stages per $200 \mathrm{cc}$. of soil transmitted virus to 100 percent of the tobacco plants used in an experiment, and in another experiment a single nematode was sufficient to inoculate virus to 60 percent of the bait plants, while 10 nematodes transmitted CTRV to all the plants. Sol and Seinhorst in 1961 (24) obtained 40-percent transmission with a single T. pachydermus, and Van Hoof 1963 transmitted TRV to 50 percent of Nicotiana rustica plants with single males (29). There is evidence that single nematodes transmit the following NEPO viruses: Grapevine-fanleaf, arabis mosaic, strawberry latent ringspot virus, and tomato ringspot virus $(19,17,5,27)$.

The efficiency of a vector is only a relative classification which is probably affected by the technique used. When a mixture of soil and coarse sand $(1: 3)$ was used instead of regular potting soil, and temperature, soil moisture, and age of the bait plants were controlled, single adult females were capable of transmitting CTRV to all Glurk tobacco plants used (table 4).

All single adult females of $T$. allius transmitted the virus, but the percentage transmission with single larvae decreased with second-, fourth-, and third-stages respectively. Some of the single larvae selected may have just molted and feeding had not taken place after molting. Should the virus be lost through the molt, nematodes that had not fed after molting would not be infective, and this possibility may be increased when using nematodes of all life-cycle stages. Furthermore, the activity of the different stages in the life cycle may not be the same, and females may feed for longer periods of time, thus increasing the chances of transmitting virus.

According to Sol (23) larvae, adult females, and males of T. pachydermus, separately, transmitted TRV. Grapevine fanleaf virus is transmitted by both larvae and adults of $X$. index (20), and arabis mosaic virus (AMV) both by the larvae and adults of $X$. diversicaudatum, although somewhat more 
readily by the adults of either sex (15). Larvae of Longidorus elongatus transmitted tomato black ring virus (TBRV) but adults did not, (14) although both adults and larvae can transmit raspberry ringspot virus (RRV) (25). All developmental stages of Xiphinema americanum transmitted TomRSV with the same efficiency (27).

Trichodorus allius acquired CTRV after an access period of 1 hour on virus-infected Glurk tobacco plants, and the infective individuals were able to transmit the virus to another plant within a 1-hour access period. In both cases efficiency of transmission increased as the access period was prolonged. These aspects have not been studied with other species of Trichodorus. Among the vectors of NEPO viruses, $X$. americanum acquired tomato RSV from cucumber within 1 hour and inoculated it into healthy cucumber plants in 1 hour (27). $X$. index acquired GFV and infective nematodes transmitted it within 24 hours, according to Raski and Hewitt (20); Xiphinema diversicaudatum acquired AMV in 1 day and a field population of viruliferous nematodes transmitted it to bait plants in 3 days (18). Longidorus elongatus became infective only when allowed to feed several weeks on plants infected with TBRV and RRV $(18,14,25)$.

The minimum periods needed by the nematodes to acquire viruses from plants, and to transmit to other plants, are actually access periods and not feeding periods (9). The minimum total time-interval needed by nematodes to acquire virus from infected plants and transmit it to healthy ones, or whether the virus has a latent period in their vectors, has not been determined. Studies here indicate that the time needed to acquire and to transmit the virus is shorter than 1 hour in each case. This affords a better understanding of host-parasite relationships because it indicates that at least some nematodes, after becoming infective, feed on available plant roots in very short periods of time.

Populations of $T$. allius apparently lost the ability to transmit CTRV after molting, and no transovarial passage of the virus was demonstrated. Attempts to transmit the virus with nematodes in the process of molting were unsuccessful. These are the first studies of this type with rod-shaped viruses, but the results are similar to those obtained for some of the NEPO viruses. A low population of $X$. diversicaudatum did not transmit AMV after molting (15). Taylor and Raski (26) reported that GVF did not persist through the egg or through the molt of $X$. index. Raski and Hewitt (20) obtained similar results when they added eggs or newly hatched larvae from viruliferous females to roots of grapes.

Results here tend to support the hypothesis that the nematode-transmitted plant viruses do not persist through the egg and ecdysis. Available data do not support the extablishment of parallels between nematode- and insect-vectored viruses with respect to the classification as persistent or 
nonpersistent. The available data on acquisition and inoculation time, possible loss of infectivity through the molt, and apparent negative transovarial transmission tend to indicate that the nematode-borne viruses are of the "nonpersistent type", but ability to transmit after long periods of fallow, or feeding on a virus-immune host suggests that nematode-borne viruses are of the "persistent type". It seems more reasonable, therefore, to avoid the use of the terms "persistent" and "nonpersistent" in relation to nematode-borne viruses. The fact that nematodes lose the ability to transmit virus after molting does not necessarily imply that the virus is held and lost with the old cuticle or cuticular organs. Enzymes or hormones produced during or in the preparation of the molting process may destroy or inactivate the virus and make it impossible for the nematode to infect another plant, or the virus to reduplicate itself once in a plant cell. This may tend to suggest that the virus is held in or associated with a nematode organ or structure involved in the molting process. Not until the virus is recovered directly from molted nematodes or their exuviae, or the virus is viewed in nematode sections with the electron microscope, will this aspect be completely elucidated.

Populations of $T$. allius retain their infectivity for reasonably long periods, as evidenced by their ability to transmit CTRV to bait plants after being without a host for 20 weeks, or feeding on a virus-immune host for 27 weeks at $20^{\circ} \mathrm{C}$. This suggests that the association between CTRV and its vector is not a purely mechanical one. If the virus were carried in or on the stylet, or on the lip-region, repeated feeding on a virus-immune plant should tend to render nematodes noninfective.

Raski and Hewitt (21) demonstrated that grapevine fanleaf virus persisted in $X$. index held in moist sterile soil without a host for 30 days, and this time was extended to 122 days (21) and subsequently to 8 months by Taylor and Raski (26). Xiphinema diversicaudatum transmitted arabis mosaic virus after 31 days $(18)$ and 24 days $(15)$ when held in moist peat free from plants. Harrison and Winslow $(15)$ found that a population of $X$. diversicaudatum retained infectivity for 8 months when cultured in soil on "healthy" raspberry plants. Taylor (25) concluded that Raspberry ringspot virus persisted for at least 42 days in $L$. elongatus, but his experiments did not completely exclude the possibility that the nematodes may have had access to fragments of infected roots. Van Hoof (30) reported transmitting TRV with T. pachydermus in soil stored for 10 months at fluctuating temperatures between $3-20^{\circ} \mathrm{C}$.

Virus was recovered from $T$. allius when 1,5 , and 10 adult females were cut in water, and the resulting mixture was rubbed on cowpea leaves. The number of lesions produced and the percentage recovery of the virus were low compared to recovery when live infective nematodes were fed on 
a bait plant. This suggests that the method is not very efficient for detecting virus in infective populations. Failure to recover virus from the nematode more frequently may occur because of a low virus titer in or on the nematode. When similar live nematodes had access to roots of a bait plant the low-titer virus inoculated would reduplicate itself building up the titer in the plant cells making detection possible in 10 or more days. Moreover, systemic symptoms on bait Glurk tobacco plants developed occasionally in 8 days, but no attempt was made to recover the virus from roots exposed to viruliferous nematodes for less than 10 days.

On several other occasions virus has been recovered directly from the nematode vectors. Sänger, Allen, and Gold (22) successfully produced virus lesions on Chenopodium amaranticolor from cut Trichodorus sp., and saw rod-shaped particles similar to short particles of TRV in the same water mixture when viewed under the electron microscope. Sol, cited in Raski and Hewitt, 1963 (21) transmitted TRV by rubbing water containing cut specimens of $T$. pachydermus on a leaf of tobacco. This technique might be used in determining the site where the virus is held in nematodes, if it could be modified to obtain more stable results and a way found to use only selected parts of the nematode. It is not known at this time, whether the virus detected comes from the nematode intestine with ingested plant fluids or from body tissue.

\section{SUMMARY}

The California tobacco rattle virus (CTRV), serologically related to the Dutch strains of TRV, was successfully transmitted by three species of the nematode genus Trichodorus Cobb, 1913. Trichodorus christiei Allen, 1957 (Riverside and Shafter isolates) and T. porosus Allen, 1957, were moderately good vectors when California Wonder pepper and Glurk tobacco, respectively, both poor hosts for the nematodes, were used as sources of virus and as bait plants. Trichodorus allius Jensen, 1963 was an excellent vector and was used in all experiments on nematode-virus interrelationships. Ten nematodes were sufficient to transmit CTRV to 100 percent of the bait plants, Nicotiana glutinosa, while one and five nematodes transmitted the virus to 60 and 80 percent of the bait plants, respectively. When Glurk tobacco (Nicotiana tabacum var. Xanthi-nc) was used, all the stages of T. allius transmitted the virus with almost equal efficiency. Ten nematodes of any stage, the three larval stages and the adult females, provided 100-percent transmission; five nematodes of any stage except third-stage larvae produced similar results. When single nematodes were used, percentage transmission was as follows: Adult females, 100, second-stage larvae, 50, fourthstage larvae, 33.3; and third-stage larvae, 16.7. When 50 nematodes per pot were used, Trichodorus californicus Allen, 1957 did not transmit CTRV. 
Populations of $T$. allius became infective after feeding on virus-infected Glurk tobacco for 1 hour. Efficiency increased as the feeding time was increased up to 24 hours. An infective population transmitted CTRV within 1 hour after being added to the roots of a bait-plant, and efficiency of transmission increased up to 48 hours.

Evidence for transovarial transmission and transtadial passage of the virus was not conclusive. Populations remained infective for 20 weeks when kept at $20^{\circ} \mathrm{C}$. without a host and 27 weeks when feeding on a virusimmune host. Virus was recovered directly from cut nematodes when their body contents were rubbed on leaves of cowpea, Vigna sinensis (Torner) Savi.

\section{RESUMEN}

El virus llamado California tobacco rattle (CTRV), el cual está relacionado serológicamente con la cepa holandesa del TRV, fue transmitido por tres especies del género Trichodorus Cobb, 1913. Trichodorus christiei Allen, 1957 (colecciones de Riverside y Shafter en California) y $T$. porosus Allen, 1957 fueron vectores de alguna eficiencia cuando se usaron plantas de pimiento (variedad California Wonder) y de tabaco (variedad Glurk), respectivamente, como proveedoras del virus y como plantas de cebo. Trichodorus allius Jensen, 1963 fue un vector excelente, por lo que se usó en todos los experimentos en los que se investigaban las interacciones del virus y el nemátodo. Diez especímenes de esta especie fueron suficientes para transmitir el CTRV a todas las plantitas de Nicotiana glutinosa usadas como cebo, mientras que uno y cinco especímenes transmitieron con menos eficiencia (60 y 80 por ciento, respectivamente). Cuando se usó el $N$. tabacum var. Xanthi-nc como cebo, todas las etapas larvales usadas (segunda, tercera y cuarta) y las hembras adultas transmitieron con casi igual eficiencia. Diez especímenes, de cualquiera de las etapas, transmitieron al 100 por ciento de las plantas expuestas; cinco especímenes, de cualquiera de las etapas excepto la tercera, ejercieron el mismo efecto. Cuando se usó un solo espécimen, la proporción de transmisión fue como sigue: hembras adultas, 100 por ciento; segunda etapa, 50 por ciento; cuarta etapa, 33 por ciento; y tercera etapa, 16.7 por ciento. No se obtuvo transmisión alguna con 50 especímenes de $T$. californicus Allen, 1957.

Las poblaciones del $T$. allius adquirieron el virus después de exponerse durante 1 hora a una planta infectada del virus. La habilidad para transmitir el virus aumentó cuando se extendió el período de exposición hasta 24 horas. Una población infectada transmitió el CTRV dentro de un período de 1 hora después de añadirse a las raíces de una planta indicadora, originalmente libre del virus, y la efectividad para transmitir aumentó hasta 48 horas. 
La evidencia obtenida parce indicar que el virus no pasa a través del huevo a las larvas y que el nemátodo pierde el virus cuando muda su cutícula. Las poblaciones del nemátodo retuvieron el virus por 27 semanas cuando se alimentaron de una planta inmune al virus y 20 semanas cuando se mantuvieron libres de la planta hospedadora. Se recobró el virus directamente del nemátodo cuando se cortaron varios especímenes en agua y se frotaron sus contenidos en hojas de plantas indicadoras de frijol, Vigna sinensis (Torner) Savi.

\section{LITERATURE CITED}

1. Allen, T. C., A strain of tobacco rattle virus from Oregon-grown potatoes, Plant Dis. Reptr. 47 (10): 920-3, 1963.

2. Behrens, J., Weiter Beiträge zur Kenntnis der Tabakpflanze, XIV, Die Mauche (Mauke) des Tabaks. Handw. Versuchstal. 58: 442-47, 2889.

3. Bos, L., and van der Want, J. P. H., Early browning of pea, a disease caused by a soil- and seed-borne virus, Tijdschr. Plantenziekten 68: 368-90, 1962.

4. Cadman, C. H., Biology of soil-borne viruses, Ann. Rev. of Phylopath. 1: 14:-72, 1963.

5. —_, Pathogenesis by Soil-Borne Viruses, Ecology of Soil-Borne Plant Pathogens: Prelude to Biological Control (K. F. Baker and W. C. Snyder, eds.), University of California Press, Berkeley, Calif., pp. 302-21, 1965.

6. Campbell, R. N., Grogan, R. G., and Purcifull, D. E., Studies on the transmission of the virus causing big vein of lettuce. Phylopalhology, 58: 5, 1962.

7. de Zoeten, G. A., and Shalla, T. A., Purification and characterization of California tobacco rattle virus, Phytopathology, 66: 738-43, 1966.

8. Gold, A. H., Bardin, R., and Grogan, R., An apparent strain of tobacco rattle virus associated with a yellow spotting of lettuce, Phytopathology, 53: 1139, 1963.

9. Harrison, B. D., The biology of soil-borne plant viruses, Advances in Virus Res. 7: 131-61, 1960.

10. - Soil-Borne Viruses, Plant Pathology Department, Rothamsted Exp. Sta. Rep. 1960: 118, 1961.

11. - The Transmission of Plant Viruses in Soil, Plant Virology (M. K. Corbett and H. D. Sisler, eds.), University of Fla. Press, Gainesville, Fla., pp. 118-47, 1965.

12. - Specific nematode vectors for serologically distinctive forms of raspberry ringspot and tomato black ring viruses, Virology $22(4): 544-50,1964$.

13. - , and Cadman, C. H., Role of a dagger nematode (Xiphinema sp.) in outbreaks of plant diseases caused by arabis mosaic virus, Nature (London) 184: 1624-6, 1959.

14. - Mowat, W. P., and Taylor, C. E., Transmission of a strain of tobacco black ring virus by Longidorus elongatus (Nematoda), Virology 14: 480-85, 1961.

15. - and Winslow, R. D., Laboratory and field studies on the relation of arabis mosaic virus to its nematode vector Xiphinema diversicaudatum (Mikoletsky), Ann. Appl. Biol. 49: 621-33, 1961.

16. Hewitt, Wm. B., Raski, D. J., and Goheen, A. C., Nematode vector of soil-borne fanleaf virus of grapevines, Phytopathology 48 (11): 586-95, 1958. 
17. Jensen, H. J., and Allen, T. C., Transmission of tobacco rattle virus by a stubby-root nematode, Trichodorus allius, Plant Dis. Replr. 4 (5): 333-4, 1964.

18. Jha, A., and Posnette, A. F., Transmission of arabis mosaic virus by the nematode Xiphinema diversicaudalum (Micol.), Virology 18: 119-23, 1961.

19. Oswald, J. W., and Bowman, T., Studies on a soil-borne potato virus disease in California, Phytopathology, 48: 396, 1958.

20. Raski, D. J., and Hewitt, W. B., Experiments with Xiphinema index as a vector of fanleaf of grapevines, Nematologica 5: 166-70, 1960.

21. - and Hewitt, Wm. B., Plant-parasitic nematodes as vectors of plant viruses, Phytopathology 58: 39-47, 1963.

22. Sänger, H. L., Allen, M. W., and Gold, A. H., Direct recovery of tobacco rattle virus from its nematode vector, Phylopathology, 52: 750, 1362.

23. Sol, H. H., Some data on the occurrence of rattle virus at various depths in the soil and on its transmission, Neth. J. Plant Path. 69: 208-14, 1963.

24. - and Seinhorst, J. W., The transmission of rattle virus by Trichodorus pachydermus, Tijdschr. Plantenzickten 67: 307-311, 1961.

25. Taylor, C. E., Transmission of raspberry ringspot virus by Longidorus elongalus (de Man) (Nematoda: Dorylaimoidea), Virology 17: 493-94, 1962.

26. - and Raski, D. J., On the transmission of grape fanleaf by Xiphinema index, Nematologica 10: 489-95, 1964.

27. Téliz, D., Grogan, R. G., and Lownsbery, B. F., Transmission of tomato ringspot, peach yellow bud mosaic, and grape yellow vein viruses by Xiphinema americanum, Phylopathology 56: 658-663, 1966.

28. Van Hoof, H. A., Trichodorus pachydermus and T. teres, vectors of the early browning virus of peas, Tijdschr. Plantenzickten-Zickten 68: 391-396, 1962.

29. - - Het verbond Tussen het optreden van stengelbont (Ratelvirus) de besmetting van vanglolanten en het voorkomen van Trichodorus soorten (The correlation between the incidence of stem mottle (Rattle Virus) the infection of Bait-Seedlings and the occurrence of species of Trichodorus (1963), Landbonwhogeschool en de Opzoekingo tatious uanch Staat de Gunt 28 (3): 1001-1010, 1963.

30. - Serial transmission of rattle virus by a single male of Trichodorus pachydermus Seinhorst, Nematologica 10: 141-44, 1964.

31. Walkinshaw, C. H., and Larson, R. H., A soil-borne virus associated with the corky ringspot disease of potato, Nature 181: 1146, 1958.

32. - Griffin, G. D., and Larson, R. H., Trichodorus christiei as a vector of potato corky ringspot (tobacco rattle) virus, Phytopathology 51 (11): 806-8, 1961. 